\title{
De spiritualiteit van O. Noordmans
}

\author{
J.D.Th. Wassenaar
}

\begin{abstract}
Recent discussions of "a contemplative turn in theology" disclose greater preference for a turn away from an abstract, cognitive, intellectual way of speaking. Dr. O. Noordmans (1871-1956) demonstrated such a turn much earlier with a theology rooted in the "womb of piety" as experienced in his parental home. Reformed theology is characterized by earnestness and simplicity, not rooted in a school; it has a strong eschatological focus. Critical response charged Noordmans' theology with spiritualism and world-avoidance. Against this critique, this essay argues that this spiritualism is best understood as a historical spiritualism, in which the concrete reality of church and world is always present.
\end{abstract}

\section{Aanleiding en inleiding}

Van 15 tot 17 januari 2019 hield de in 2018 opgerichte Vereniging voor Theologie haar eerste congres. Het thema was: 'Een contemplatieve wending in de theologie?' In de toelichting sprak het bestuur over een toenemend bewustzijn dat theologisch spreken en denken, mede door de moderniteit, in allerlei opzichten intellectueel, abstract en cognitief is geworden. Ondertussen is deze oriëntatie steeds meer onder druk komen te staan. Men kan stellen dat er thans sprake is van een andere benadering, en wel van herleving van het oude adagium lex orandi, lex credendi, lex vivendi. De vraag die zich dan voordoet, is: wat betekent dat voor de theologische bezinning? In toegespitste vorm: 'Voor de systematische theologie is de vraag bijvoorbeeld wat het voor haar betekent dat ze verbonden is met contemplatie. Wat verandert er daadwerkelijk systematisch-theologisch als je het geleefde geloof als een bron voor de theologie beschouwt?'

Op het hierboven genoemde congres heeft $\mathrm{K}$. Blei een lezing gehouden over het contemplatieve karakter van de theologie van O. Noordmans. ${ }^{1} \mathrm{De}$ spreker verdedigde de volgende stelling: 'Als zich vandaag een 'contemplatie-

1 Zie Karel Blei, 'Ingebed in 'de schoot der vroomheid'. Het contemplatieve karakter van Noordmans' theologie', in: Nederlands Theologisch Tijdschrift 73 (2019) nr. 3, 235-247. 
ve wending in de theologie' voordoet, dan kan gezegd worden dat die wending zich bij Noordmans al ruim tachtig jaar geleden heeft aangekondigd. Hij was zijn tijd royaal vooruit.' Blei betoogde dat Noordmans' theologie ingebed is in 'de schoot der vroomheid'. Daarbij moet gedacht worden aan de kerk als moeder, zoals die gestalte aangenomen heeft in de huiskerk. Die beleefde werkelijkheid is de veronderstelling van heel Noordmans' theologiseren. Vervolgens attendeerde de spreker op de pastorale spits van zijn reformatorische dogmatiek. Noordmans dacht vanuit de kerk, niet vanuit wat hijzelf 'de school' noemde. Blei lichtte dat uitvoerig toe door in te gaan op de scheppingsleer van Noordmans.

In dit artikel wil ik om te beginnen onderstrepen dat Noordmans' theologie ingebed is in 'de schoot der vroomheid'. Wat hij in dat opzicht van huis uit meegekregen heeft, is niet alleen bepalend geweest voor zijn levenshouding als gereformeerd (puriteins) gelovige, maar ook voor zijn ontwikkeling als reformatorisch theoloog. Vervolgens probeer ik duidelijk te maken dat er bij Noordmans sprake is van een sterke eschatologische gerichtheid. Een en ander roept meteen wel een vraag op: of zijn spiritualiteit niet als een vorm van spiritualisme gezien moet worden. Ik ga die beoordeling (dan wel veroordeling) ten slotte bestrijden. Onder het motto: als bij Noordmans al van spiritualisme gesproken zou moeten worden, dan wel van historisch spiritualisme. ${ }^{2}$

Oepke Noordmans was 'de geniaalste reformatorische theoloog van Nederland'3. Hij werd op 18 juli 1871 in een boerengezin in het Friese Oosterend geboren. Hij bracht het grootste deel van zijn jeugd in Scharnegoutum door. $\mathrm{Na}$ zijn theologische studie te Leiden en te Utrecht diende hij de hervormde gemeenten Idsegahuizen-Piaam (1903), Suameer (1910) en Laren in Gelderland (1923). Hij heeft tweemaal op de nominatie gestaan om kerkelijk hoogleraar te worden, maar het professoraat ging beide keren aan hem voorbij. Wel verleende de Rijksuniversiteit Groningen hem een eredoctoraat, in 1935. Op 31 december 1943 ging hij officieel met emeritaat, na de bezettingstijd ook praktisch. Hij overleed in 1956.

2 Vgl. Noordmans, 'Historisch spiritualisme. Een herinnering aan de vrijzinnigen', in: Verzamelde Werken (voortaan: VW, Kampen 1978-2004), 188-204. Vgl. J.T. Bakker, 'Verbroken evenwicht - historisch spiritualisme', in: H.W. de Knijff, A. van der Kooi en G.W. Neven (red.), Noordmans voor het voetlicht, Kampen 2006, 27-39.

3 H. Berkhof, 'De stand van het Credo in de Hervormde Kerk', in: H. van der Linde en F. Thijssen (red.), Geloofsinhoud en geloofsbeleving. Een peiling binnen Reformatie en katholieke Kerk in Nederland, Utrecht/Antwerpen 1951, 122. 
Noordmans was een van de oprichters van de Bond van Nederlandse Predikanten. Van 1921 tot 1928 maakte hij deel uit van het hoofdbestuur van deze bond. Van 1931 tot 1938 vervulde hij een leidende rol in de vereniging 'Kerkopbouw', waarin gewerkt werd aan vernieuwing van de Nederlandse Hervormde Kerk. Hij leverde ook een substantiële bijdrage aan de totstandkoming van de hervormde kerkorde van 1951.

\section{De godsdienstige afkomst}

Oepke Noordmans was een van de kinderen van Durk Piers Noordmans en Gerbrig Oepkes de Roos. Hij schreef eens over zijn vader: 'Staat, kerk en school genoten levendige belangstelling.' ${ }^{4}$ Noordmans sr. zat namens de christelijk-historischen in de raad van Wymbritseradeel, later als wethouder. In Scharnegoutum had hij als ouderling een leidinggevende positie in de kerkenraad. Tevens was hij geruime tijd lid van het provinciaal kerkbestuur. Daarnaast was hij een invloedrijk lid van de Provinciale Friese Vereniging van Vrienden der Waarheid, in welk gezelschap het Friese Reveil georganiseerd was. In Tzum en in Oosterend was hij betrokken bij de oprichting van een christelijke school, in het laatstgenoemde dorp was hij ook voorzitter van het schoolbestuur.

D.P. Noordmans was streng puriteins opgevoed en in dat spoor ging hij ook verder: 'Die zelfde puriteinse levensopvatting en religieuze tucht hield uit $\mathrm{z}$ 'n leven geweerd alle meer uitgelaten vrolijkheid, elk ruw woord, zelfs elk sterk woord.'5 De belangstelling van Noordmans sr. ging in het bijzonder uit naar de geschriften van Da Costa, Groen van Prinsterer en J.A. Wormser; met veel genoegen las hij ook het dagboek van W. de Clercq. De namen van andere Reveilfiguren waren bij hem eveneens zeer bekend. Verder correspondeerde hij met zijn hervormde geestverwant Ph.J. Hoedemaker en kruiste hij de degens met de gereformeerde leidsman A. Kuyper. Hij schreef ook twee boekjes: Eenige opmerkingen over de Leer van den Doop in het algemeen en van den Kinderdoop in het bijzonder, zooals die door onze vaderen is geformuleerd (1899) en De Aard en het Wezen der Evangelische Heiligmaking gegrond in de zending van Jezus Christus als den gezondene des Vaders, in de gelijkheid des zondigen vleesches volgens Rom. 8: 3 en 4 (1905). In het eerste is verwantschap met de visie van Wormser te bespeuren, in het tweede met die van H.F. Kohlbrugge.

O. Noordmans was dankbaar voor zijn godsdienstige afkomst. In een

4 Brief 285 (O. Noordmans aan G.A. Wumkes, 19 mei 1914), in: $V W$ dl. 9A.

5 Brief 285 . 
lezing zegt hij: 'Ik stam uit een gezin, waarover nog iets van de naschemer van het Réveil lag (...)'6 In een andere laat hij weten dat hij komt 'uit een gezin, waarin het Réveil naleefde en waar de theologische en kerkelijke vragen in de huiskamer met gasten van allerlei richting werden besproken.'7

\section{Het Friese Reveil}

De aanduiding 'het Reveil' moet hier als 'het Friese Reveil', een variant van de internationale beweging, gelezen worden. ${ }^{8}$ De leer van de aanhangers ervan kwam voor een groot deel overeen met die van de conventikels die in de Afscheiding van 1834 samenvloeiden. Het ging de orthodox-piëtistische stroming echter niet alleen om de rechte leer, maar ook om de levende vroomheid. In het geloofsleven was men methodistisch; men kende een innige gebedspraktijk. De geloofservaringen werden wel in samenkomsten gedeeld. J. Hobma typeert de sfeer van zo'n bijeenkomst in zijn ouderlijk huis als volgt: 'De kamer had zulk een ander aanzien dan gewoonlijk. De eenvoudige rieten stoelen stonden in een grooten kring geplaatst; op verscheidene daarvan kerkboekjes, testamentjes, bijbeltjes en een simpel vurenhouten lessenaartje op een niet te groote tafel wees de plaats aan, waar straks zou zitten de geestelijke oudste van het gezelschap, dat men blijkbaar verwachtende was. Dr. Wumkes ${ }^{9}$ noemt er verscheidene op, die ik zoo in mijn ouders huis bijeen gezien heb. Het best herinner ik mij het lange, maar innige gebed, o.a. van Radersma, den bakker; de ernstige bespreking van de Schrift, die volgde onder het gebruik van koffie met een klontje, was voor ons te zwaar.'10

In de kerk waren onderwerpelijke predikers, die de nadruk legden op persoonlijke geloofservaringen, zeer geliefd. Men had er verre reizen voor over om die te horen. Het belangrijkste verschil tussen degenen die met de Afscheiding meegingen en de vertegenwoordigers van het Friese Reveil betrof de visie op de kerk. De Reveilmensen waren in het algemeen sterk tegen separatistische ten-

6 Noordmans, 'Kritieke spanningen in de gereformeerde theologie', in: $V W$ dl. 4, 107.

7 Noordmans, 'Verschuivingen in de theologie van de laatste honderd jaar', in: VW dl. $4,22$.

8 Zie G.A. Wumkes, It Fryske Réveil yn portretten, Snits 1911'1, Boalsert 19382, Het Friese Reveil in portretten, Kampen 1994¹, 1998². Vgl. Fred van Lieburg, 'Een wereldwijde opwekking in het protestantse vaderland. De historiografie van het Nederlandse Réveil', in: Fred van Lieburg (red.), Opwekking van de natie. Het protestantse Réveil in Nederland, Hilversum 2012, 249v.; Jan Dirk Wassenaar, 'De vrome Fries. Receptie en betekenis van It Fryske Réveil van G.A. Wumkes', De Vrije Fries 98 (2018), 22-37.

9 Zie noot 8.

10 J. Hobma, 'Het Friesche Réveil', Stemmen voor Waarheid en Vrede 52 (1915), 812. 
densen gekant. Hun kerkelijke trouw bleek vooral in de nadagen van het Reveil, toen de Doleantie opkwam. Voor hen was Kuyper een scheurmaker.

Met de bevindelijke vroomheid hing een pessimistische visie op de wereld en het leven samen. De wereld zag men als een poel van zonde. Het alledaagse bestaan met z'n soms zo oppervlakkige vertier vond men bedenkelijk. Een ingetogen leven met mijding van de wereld en onthouding van drank, kermisbezoek en dergelijke kenmerkte de Reveilman. Zo was er sterke aandacht voor de christelijke zeden en overeenkomstig strenge controle op een puriteinse levenshouding.

Het Friese Reveil beperkte zich niet tot het kerkelijke leven, het had ook invloed op de politieke bewustwording van 'de confessionelen'.

\section{De schoot der vroomheid}

In de 'Dankrede' na zijn erepromotie bepaalde Noordmans zijn gehoor bij 'de huiskerk' van zijn jeugd: 'Ik zou graag nog iets zeggen van meer elementaire dingen, over sfeer en stemmen. Over de schoot der vroomheid, de kerk, waarin ook mijn theologie is ingebed. Niet allereerst aan het kerkelijk instituut denk ik nu, maar aan de kerk als moeder. Ik denk aan de sfeer en de stemmen, zoals die openbaar worden in de huiskerk en de groep. De Schrift leerde ik kennen viva voce gelezen en niet als palimpsest. De mystieke tonen van psalmen en gezangen streken over het bewogen leven. Het gebed was geen formulier maar gemoduleerd, zoals de Geest gaf uit te spreken.'11 In dit verband zij nog het volgende vermeld: Noordmans constateert in 1940 dat het bijbel lezen in de gezinnen is afgenomen: 'In wijde kringen is dat uitgesleten. (...) Ook het gebed vóór en na het eten is in vele gezinnen uitgesleten. Wanneer het gezin ophoudt kerk te zijn, zullen de gezinnen samen óók geen kerk meer vormen. ${ }^{\prime}{ }^{12}$

'De mystieke tonen van psalmen en gezangen': dat doet denken aan twee meditaties van Noordmans. In een overdenking over 1 Korintiërs 13:13a schreef hij: 'Op het orgel in mijn ouderlijk huis stonden drie lange en wijde eikehouten pijpen. Zij waren eigenlijk een toegift van de orgelbouwer. Want zij hoorden thuis op een 16-voets register, waarvoor overigens in dit instrument geen plaats was. Alleen deze drie konden er nog net staan: de a, de bes en de b. Zij gaven grond aan het hele spel. Wanneer ik op stille avonden, op het uur waarop de avondpsalm gezongen werd, van elders thuis kwam, drongen deze drie stemmen reeds op een halve mijl afstands tot mijn oor door.

11 Noordmans, 'Dankrede', in: $V W$ dl. 4, 15.

12 Archief classis Zutphen van de Nederlandse Hervormde Kerk, 'Vergadering kerkeraden ring Zutphen, 27 maart 1940'. 
Dan werd ik van verre reeds opgenomen in deze kathedraal van geluid. Ik ging er binnen, lang voordat ik de deur der woning had bereikt. Rondom het huis, naar alle zijden en naar boven, stond de hele atmosfeer hoorbaar in trilling en het hart beefde mee vanwege de heiligheid van deze tempel, waarin ik minuten lang kon gaan, voor ik de zangers en de speellieden bereikte. Geen Domorgel heeft mij ooit een zo sterk gevoel van wijding kunnen geven als deze drie, wanneer zij rondom die woning een tempel deden rijzen. En geen kerk bracht mij ooit een zo grote zekerheid bij van thuis te komen bij God.'13 - Het huisorgel van de familie Noordmans staat sedert medio 2018 in de Johanneskerk te Burchwert. ${ }^{14}$

Het heeft er alle schijn van dat deze achtergrond een grote rol gespeeld heeft in Noordmans' denken inzake liturgie, waarover hij de degens onder meer kruiste met prof.dr. G. van der Leeuw. ${ }^{15}$ Ze zouden het nooit eens worden. In 1939 merkte Van der Leeuw over Noordmans' boek Liturgie op: 'Hij vertrouwde mij toe, dat hij dit boek schreef omdat hij in het huidig liturgisch streven gevaar zag voor de kerk, die hij liefheeft en waarin hij als kleine jongen voor het eerst boven de bank kwam uitkijken. Die wilde hij liefst ongerept bewaren. Ik kan dat begrijpen. De beschrijving, die Noordmans geeft van de kerk zijner kinderjaren, kan ik hogelijk bewonderen. ${ }^{16}$ Van der Leeuw voegde er wel aan toe: 'Maar ik kan als theoloog deze manier van doen niet billijken.'

Overigens: er is een aanwijzing dat Noordmans zich al veel eerder dan ten tijde van het debat met Van der Leeuw als tegenstander van liturgische vernieuwing geprofileerd heeft. ${ }^{17}$ Noordmans sprak op 18 december 1909 ter

13 Noordmans, 'Deze drie', in: $V W$ dl. 8, 387. Vgl. Noordmans, 'De zon, het orgel en de preek', in: Noordmans, VW dl. 6, 300; J.D.Th. Wassenaar, 'Het orgel 'een hemelse heiligheid'? Dr. O. Noordmans (1871-1956) en de kerkmuziek', Documentatieblad voor de Nederlandse Kerkgeschiedenis na 180021 (1998) nr. 49, 44-52; J.D.Th. Wassenaar, Met het oor waarneembare voetstappen Gods. Dr. O. Noordmans en prof.dr. G. van der Leeuw over het orgel en de organist (Willem de Zwijgerstichting 2012).

14 Zie J.D.Th. Wassenaar, 'Vol sfeer en stemmen'. Het Adema-huisorgel van de familie Noordmans. Uitgave van de Stichting tot behoud van het Nederlandse Orgel, publicatie nr. 88 (voorjaar 1988), 21-23.

15 Zie Het debat Noordmans - Van der Leeuw (met bijdragen van K.W. de Jong en M. Barnard), Noordmans Cahier 7, z.p. 2008; J.D.Th. Wassenaar, Met het oor waarneembare voetstappen Gods.

16 G. van der Leeuw, 'Liturgie in de crisis', in: G. van der Leeuw, O. Noordmans en W.H. van de Pol, Liturgie in de crisis, opgenomen in: Noordmans, VW dl. 6, 167.

17 Zie J.D.Th. Wassenaar, Noordmans in Friesland. Bijdrage tot de biografie van een kerkvader, Zoetermeer 1999, 118. 
gelegenheid van de ingebruikneming van een nieuw orgel in de kerk van Idsegahuizen. Oud-catechisant W.B. Visser vertelt daarover in een brief van 28 juni 1909 aan Noordmans: 'Wij herinneren ons ook nog de inwijding van het herstelde pijporgel. Ik meen nog te weten, dat u toen zei dat orgelbegeleiding van het zingen niet oorspronkelijk, niet bijbels was.' Visser voegt eraan toe: 'Mocht $\mathrm{u}$ dat niet gezegd hebben, wij houden deze gedachte evenwel voor waar te zijn. Als het koor of de muziek of het rithme de tekst overstemt of verdonkeremaant dan is die kunst mij een ergernis. De wereld is niet geschapen door muziek maar door het Woord Gods.' Daarna gaat Visser in op de liturgische ontwikkelingen in zijn dagen, geheel in de geest van Noordmans.

\section{Andere jeugdherinneringen}

De openingsmeditatie in de bundel Gods poorten, over Psalm 24:4 (berijmd), begint als volgt: 'Het was op een der eerste dagen van april 1877, dat ik aan de hand van een zes jaar oudere zuster, die nu reeds lang met Gods engelen zijn aangezicht aanschouwt, één mijner eerste schoolgangen maakte. (...) Toen voegde de psalm, terwijl wij op de landweg voortgingen, zich bij ons. Hij wandelde als derde met ons mee, zoals Jezus met de Emmaüsgangers. Hij woei om ons heen, zoals de Heilige Geest om de discipelen op het Pinksterfeest. (...) Als in die zelfde april-maand op de zaterdag de namiddagschool en de avondschool stilstonden en wij samen reeds op de middag huiswaarts keerden; als wij dan aan de rode landweg kwamen tussen de groene weiden, dan verhoogden de poorten de boog, en wij gingen er onder door met een stille, blijde verbazing. Dan werd het zonlicht tot een verheffing (Ps. 4:7) en tot een opening naar het rijk der klare waarheid. Dan beitelde zich de leeuwerik in het blauw des hemels zijn trap, klimmende en het 'lied der trappen' zingende tot de top. En dan rinkelden vandaar de heldere kraaltjes van het geluid al stuitend naar beneden tot voor onze voeten. Door deze poorten en langs deze toon- en hemelladders gingen wij, Gods engel en ik, 'verrukt ten reije'.'18

Ook andere herinneringen hebben op enigerlei wijze betrekking op de natuur. In de lezing 'Lân en libben' (1918) zegt Noordmans in zijn omschrijving van het begrip 'land': 'En nu denk ik aan het nog te velde staand, ongemaaid gewas, in de maand mei, als de wind er doorheen ruist en de lange grashalmen zich buigen, als hield een koning er zijn intocht. Ik heb een jochie gekend van zes jaar ${ }^{19}$ die dat zo graag mocht zien en horen, dat hij er toch heen wou, ook al moest hij bij de varkens langs, waar hij doodsbenauwd voor

18 Noordmans, 'Gods poorten', in: $V W$ dl. 8, 103.

19 Het moge duidelijk zijn dat Noordmans zichzelf bedoelt. 
was. Dan moest zijn ouder zusje hem haar schort over het hoofd doen, zodat hij de varkens niet zag. En zo kwam hij dan in het beloofde land. Ik denk dat hij zo iets voelde als koning David toen die de wind door de moerbeibomen hoorde ruisen, of als de oude Grieken die de wind door de oude bomen te Dodona hoorden gaan. Dan was er meer dan wind en bomen en zo was er voor dat jongetje meer dan geur en een dwarrelende zomerwind.'20 In de meditatie 'Zoeken en vinden' (1947-1948) schrijft Noordmans dat hij vaak in het vroege voorjaar kievitseieren gezocht heeft; hij zegt dan: 'De kievit is niet alleen oprecht gelijk de duiven, maar ook voorzichtig gelijk de slangen, als de christen (Matth. 10:16). Zijn misbaar dient om uw aandacht af te leiden van de juiste plek, waar de strootjes liggen, die zijn nest uitmaken. Dit geheim te ontdekken, dat heet nu zoeken. Het veld is wijd als de wereld; het plekje nietig; het ei heeft schuilkleuren. (...) En dan het vinden. Om deze ervaring is men in staat geweest op te geven alles wat men had (Matth. 13:44, 46). Zij stelt niet teleur. Hoe schaamachtig ligt daar die kleine verborgenheid. Heel de tekentaal, al de gelijkenissen in het uitspansel waren daar, opdat gij ziende niet zoudt zien en horende niet horen (Matth. 13:13). En nu hebt gij, die zocht, toch gevonden. (...) Daaraan gelijk is het Koninkrijk der hemelen. De verborgenheid der godzaligheid is groot (1 Tim. 3:16). ${ }^{21}$ In de meditatie 'Gods altaren' (1947-1948) schrijft Noordmans over de zwaluw: 'Het meest spreekt de zwaluw hier tot ons, vooral ook omdat wij haar ook in onze woningen hebben zien in- en uitvliegen. Hoe vertrouwd is ons deze vogel en haar scherende vlucht, die aan die vlucht ook haar naam ontleent in de taal van de psalm. Wij denken er aan, hoe wij 's avonds bij het afsluiten van bepaalde deuren er rekening mee hielden of de zwaluw al binnen was. Ook zij scheen zich daarvan bewust en liet dan niet lang op zich wachten. In zekere zin was deze vogel ons heilig, meer dan de andere, die buiten nestelden. Niet alleen Gods huis, maar ook het eigen huis heeft zijn altaren en de zwaluw legde daar haar jongen neder. Dit schiep een heilig gastrecht, dat onder Gods bijzondere hoede stond. Wie ook maar éénmaal in jeugdige hybris, de schennende hand uitstrekte naar het nest, voelt een vleug van schaamte en schuldigheid over zijn ziel varen, als hij er aan terugdenkt, levenslang.' 22

In al deze jeugdherinneringen valt de vergelijking tussen de 'gestalte' van het gewone bestaan en het 'gehalte' van het koninkrijk van God op. In dit verband wijs ik op een opmerking van Noordmans over de eigen kaart van het

20 Noordmans, 'Lân en libben', in: $V W$ dl. 1, 328/329.

21 Noordmans, 'Zoeken en vinden', in: $V W$ dl. 8, 124v. Vgl. brief 821 (W.A. Hoek aan O. Noordmans, 20 februari 1948).

22 Noordmans, 'Gods altaren', in: $V W$ dl. 8, 159v. 
evangelie, in de meditatie 'Golgotha' (1948-1949): 'Deze topografie van de heilsfeiten, in geest en waarheid, vindt haar afspiegeling in onze jeugdherinneringen aan de verhalen uit het Evangelie. Mij althans staat daarbij niets voor de geest, wat op een landkaart gelijkt. De paaszaal, Gethsemané, de zaal van Kajafas, het rechthuis van Pilatus, de via dolorosa, Golgotha, de hof van Jozef van Arimathea lokaliseerden zich in en rondom mijn ouderlijk huis en tot op de dag van heden kan ik mij de lijdensgeschiedenis niet anders voor de geest brengen dan in deze naïeve formatie. Ik geloof, dat de intieme schroom van deze kinderlijke verbeelding dichter staat bij de ware aanbidding dan de zuiverste voorstelling, die wij met behulp van de beste commentaren zouden kunnen verkrijgen. ${ }^{23}$

\section{Ernst}

Noordmans heeft zich sterk vereenzelvigd met de gereformeerde (puriteinse) levensstijl. In de lezingen 'Gereformeerd-ethisch'24 (1928 en 1929) sprak hij daar uitvoerig over. Eerste kenmerk van de gereformeerde levensstijl noemde hij 'ernst'. Hij riep de herinnering op aan 'die grondstemming uit het ouderlijk huis (...) waarin gevouwen handen, lezing der Schrift en psalmgezang geen liturgische handelingen waren, die in het profane leven werden ingeschoven om de huiver voor het geheimzinnige wakker te houden, maar zich aansloten bij het geheel. ${ }^{25}$ In deze typering valt het werkelijkheidskarakter van de huiselijke liturgie op. Het lezen uit de Bijbel zag Noordmans als een belangrijk kenmerk van het protestantisme, zo blijkt uit het opstel 'Newman en de historie' (1944). Naar aanleiding van J.H. Newmans uitspraak 'Het protestantisme is bijbelreligie' zei hij: 'Deze wordt gelezen in de kerk, de familie en in de binnenkamer. ${ }^{26}$ In de meditatie 'Een vaste burcht' over Psalm 46:4b kwam Noordmans terug op de psalmen; hij stelde dat de protestantse gemeente die gezongen heeft 'niet alleen in haar tempels, haar kerken (...) maar misschien nog meer in haar andere bijeenkomsten en in haar huizen': 'Daardoor is de ziel van dit volk besnaard geworden en heeft ons leven een inwendig ritme gekregen, dat preludeert op de eeuwige vrede. ${ }^{27}$

Ernst als grondlijn van de gereformeerde levenssfeer was volgens Noordmans vooral gelegen in het besef van 's mensen directe verhouding tot

23 Noordmans, 'Golgotha', in: VW dl. 8, 302. Vgl. J.D.Th. Wassenaar, 'Kinderlijke verbeelding en ware aanbidding', in: HW-Confessioneel, 17 maart 2016.

24 Noordmans, 'Gereformeerd-ethisch', in: $V W$ dl. 3, 390-408 en 409-418.

25 Noordmans, a.w., 391.

26 Noordmans, 'Newman en de historie', in: $V W$ dl. 3, 285.

27 Noordmans, 'Een vaste burcht', in: VW dl. 8, 166. 
God; er is onmiddellijke gemeenschapsoefening. 'Dit staan voor God, zonder enig apparaat, zonder inrichting, zonder plechtstatig middending, geeft aan het gereformeerde leven zijn kenmerkende ernst. God is vlak bij, want het is bovenal het werk van de Heilige Geest dat op de voorgrond staat.'28 Noordmans ontkende niet dat die ernst ook in de kerk, onder de ambtelijke prediking en bij de bediening der beide sacramenten gevoeld wordt, maar de echte ernst was voor hem meer aan de persoonlijke sfeer gebonden. 'Gereformeerd geestesleven veronderstelt persoonlijke levensernst'.

Wanneer Noordmans de gereformeerde levensstijl met zijn ernst uittekent, keert hij zich vooral tegen het rooms-katholicisme. Dat is hem te pompeus, omdat het te direct op het verlossingswerk van de Zoon reageert. Zo komt men gemakkelijk tot bedwelmende mystiek. Op soortgelijke wijze brengt een te directe reactie op het scheppingswerk van de Vader gemakkelijk tot heidense toverij. De gereformeerde geloofsbeleving daarentegen kent alleen de onmiddellijkheid van de Heilige Geest.

\section{Eenvoud}

'Eenvoud' noemde Noordmans het tweede kenmerk van de gereformeerde levensstijl. Die staat in nauw verband met de ernst. De ernst is de waarheid van het leven en de eenvoud is de schoonheid ervan. Met andere woorden: 'De onmiddellijke afstand voor God verraadt in de grote levensernst zijn wezen. In de grote eenvoud van het leven neemt het zijn vorm aan.'29 De gereformeerde eenvoud vond Noordmans betoverend; 'Ik wil eerlijk bekennen dat het het mooiste is wat ik ken. ${ }^{30}$ Ook hier verwees hij naar zijn jeugd. In zijn jonge jaren had hij de eenvoud ingedronken en sindsdien kon het pompeuze hem op geen enkel terrein meer bekoren. Op hoge leeftijd schreef Noordmans nog een jeugdherinnering op die hem bij die eenvoud bepaalde, 'Eenvoud des harten', over Matteüs 5:8. ${ }^{31}$ Ze heeft betrekking op Douwe, een oud, gebogen mannetje dat jaarlijks bij de familie Noordmans op bezoek kwam. 'In mijn herinnering blijft die ontvangst bewaard als een soort feest. Ik hoor een roep: 'Douwe!' En die naam vervulde dan het gehele huis waar wij zaten. Die naam was meer dan het gebogen figuurtje. Hij omringde en omhulde dat als een wolk. Terwijl de kleine gestalte werd opgeborgen in een voor haar geschikte leunstoel, waarin de zittende houding haar enigszins oprichtte, schiep de naam een sfeer van

28 Noordmans, 'Gereformeerd-ethisch', 392.

29 Noordmans, 'Gereformeerd-ethisch', 392.

30 Noordmans, a.w., 393.

31 Noordmans, 'Eenvoud des harten', in: $V W$ dl. 8, 280-282. 
eenvoud en zuiverheid, van klaarheid en rechtheid, waarin het ons goed was te ademen. Die naam was het wezen van deze mens geworden; (...) Hij was geworden tot een eenvoudig wezen. Het beeld en de gelijkenis van Gods eenvoudigheid waren er in aan de dag getreden.' 32 Aan het einde van de meditatie sprak Noordmans over 'De herinnering (...) als aan een aanschouwelijke opvoering van de bergrede; aan een huiselijke communie en aan de beoefening van de liturgie des levens'. R. Dijkstra legt een verband met het Reveil: 'Hier staat het Réveil voor ons in levenden lijve. 't Is een schilderijtje dat ons niet meer los laat (...) een staal van het echte réveil (...)'33

Toen Noordmans de gereformeerde levensstijl met zijn eenvoud uittekende, richtte hij zich vooral tegen het verschijnsel 'cultuurmens'. Zo schreef hij in het artikel 'De Zwitserse theologie' (1926) over de waarheid die God met de twee woorden 'zonde' en 'genade' over het menselijk leven uitspreekt, waarbij hij stelde: 'Eenvoudig en geweldig is daarmee het leven geworden. En uit deze beide klinkt een sterk: Nicht Ihr! ons tegen. Een wachtwoord voor de poort der eeuwigheid, dat het volk vaak zoveel beter verstaat dan de cultuurmens. Dat in menig boerenhuis een monumentale stijl aan het leven geeft, waartegen de drukke persoonlijkheidscultuur het aflegt.' 34

Nadat Noordmans 'ernst' en 'eenvoud' uitgetekend heeft, spreekt hij in 'Gereformeerd-ethisch' over de grote kracht die achter de gereformeerde levensstijl gescholen heeft. Hij wijst op de ascese en noemt in dat verband het verwerpen van dans, kansspel en toneel. Hij ontkent echter dat in het gereformeerde leven sprake is van ascetisme. Wel van ernst, in de zin van felle geestelijke concentratie. Daardoor vallen sommige vitaal geachte delen van het menselijk bestaan als 'frivool' af. ${ }^{35}$

\section{Wereldmijding?}

De vraag doet zich voor of de benadering van Noordmans niet toch tot wereldmijding moet leiden. Dat blijkt niet het geval te zijn. De 'sterke aandachtssamentrekking op het eeuwige leven' betekent niet dat het aardse leven gehaat moet worden, zo benadrukt hij in 'Gereformeerd-ethisch'. ${ }^{36}$

In de lezing 'De kerk in de wereld' (1946) heeft Noordmans het over de 'Dopersen', die zich terugtrokken. Maar 'onze kerkelijke voorouders dachten

32 Noordmans, a.w., 281.

33 R. Dijkstra, 'Dr. O. Noordmans als persoonlijkheid', In de Waagschaal 11 (1956) nr. 30, 470.

34 Noordmans, 'De Zwitserse theologie', in: $V W$ dl. 3, 569.

35 Zie Noordmans, 'Gereformeerd-ethisch', 393.

36 Zie Noordmans, a.w., 394. 
er anders over', aldus Noordmans. ${ }^{37}$ Toch oefenden ze volgens hem ook een sterke terughouding, vooral in wat hij 'het gezellige leven' noemt. Ongetwijfeld dacht hij daarbij aan de sfeer van zijn ouderlijk huis. Hij betreurt het dat veel hervormden bezig zijn zeer slordig met hun eigen christelijke levensvormen om te gaan. Naar zijn mening heeft de kerk als gemeenschap, evenals een huisgezin, een zekere ordening nodig.

H.W. de Knijff heeft uitvoerig en diepgravend over ascese bij Noordmans geschreven. ${ }^{38}$ Volgens hem komt het er in feite op neer 'dat de mens zijn geschapen plaats zonder angst en reserve onder de tucht der eeuwigheid inneemt en daarbij de in het gebod gegeven grens (de woekering en grensoverschrijding van de levensdrift) niet overschrijdt. Hij staat dus letterlijk 'midden in het leven', sub specie aeternitatis, en daar moet hij blijven. Deze ethiek is een ethiek van maat en grensbesef, zij wordt bepaald door de geschapen, ja 'natuurlijke', positie van de mens onder het Woord van God'. ${ }^{39}$ Duidelijk is, dat ascese voor Noordmans 'een positief en constitutief grondgegeven' is, ze heeft volgens De Knijff zelfs 'charme'. De auteur biedt ook een actualisering in onze huidige economische werkelijkheid aan. Hij stelt dat onze plek om te leven wordt bedreigd door expansiedrift, waarbij het gevaar van levensbedreigende demonisering op de loer ligt. Naar zijn mening zijn de vraagstukken van consumptie- en milieu-ethiek in ons technocratische tijdperk zonder een scheut van de door Noordmans bepleite levensstijl onoplosbaar. ${ }^{40}$ Of die algemeen ingang zal vinden, valt zijns inziens te betwijfelen. Hij verwacht: 'Het zal dan wel zo gaan, als het Noordmans verging bij zijn nota 'Over de genotzucht', ${ }^{41}$ op verzoek van de synode geschreven, maar als onbruikbaar verworpen.' 42

In de door De Knijff aangehaalde conceptnota, die uit 1946 dateert, schrijft Noordmans dat gelovigen niet de wereld, maar Christus gelijkvormig moeten worden. Noordmans: 'Wanneer wij met Hem willen opstaan en de gelijkheid aan zijn heerlijk lichaam deelachtig worden (Fil. 3:20), dan moeten wij ook zijn dood gelijkvormig worden (Fil. 3:10). Dat betekent een rem op onze

37 Zie Noordmans, 'De kerk in de wereld', in: $V W$ dl. 6, 629.

38 Zie H.W. de Knijff, 'Noordmans over ascese, soberheid en puritanisme', in: Soberheid en nieuwe economie in het spoor van O. Noordmans, Noordmans Cahier 2, Groningen 2002, 19-35. Vgl. B. Breek, 'Noordmans en het puritanisme', Nederlands Theologisch Tijdschrift 27 (1973) nr. 2, 146-175.

39 De Knijff, 'Noordmans over ascese, soberheid en puritanisme', $28 \mathrm{v}$.

40 Vgl. H.W. de Knijff, Tussen woning en woestijn. Milieuzorg als aspect van christelijke cultuur, Kampen 1995.

41 Noordmans, 'Concept-herderlijk schrijven over de genotzucht', in: $V W$ dl. 6, 509-512.

42 De Knijff, 'Noordmans over ascese, soberheid en puritanisme', 31. 
natuurlijke lichamelijkheid, die niet straffeloos kan worden afgezet. Een christenheid die dat doet, vervalt in de diepte des Satans (Openb. 2:24). Wanneer de dingen zo staan, dan behoort de gemeente op dit punt uit haar slaap te ontwaken.' ${ }^{43}$ Maar 'een rem op onze natuurlijke lichamelijkheid' is wel iets anders dan het aardse leven haten.

\section{De uitwendige ellende}

In het kader van de vraag naar wereldmijding bij Noordmans wil ik nog op andere aspecten van zijn theologie wijzen.

In november 1945 publiceerde Noordmans de baanbrekende meditatie 'Zondaar en bedelaar'. ${ }^{44}$ Deze overdenking, over de gelijkenis van de Farizeeër en de tollenaar (Lucas 18:9-14) en die van de rijke man en de arme Lazarus (Lucas 16: 19-31), is gestempeld door de ervaringen van de Tweede Wereldoorlog. Met het oog op de nood die toen aan het licht gekomen was, stelt Noordmans dat het evangelie van het Koninkrijk twee kanten heeft. Het heeft zijns inziens niet alleen betrekking op de nood van de schuld, maar ook die van het 'lot': 'Jezus is op aarde gekomen om zondaren zalig te maken, maar op aarde heeft hij de armen reeds zaliggesproken. Deze zaligspreking mogen wij hun niet ontnemen. Wij mogen van Lazarus ook niet eisen dat hij zich eerst oefent om de bede van de tollenaar te stamelen. In hoeverre de uitwendige ellende, de nood des levens, de armoede een innerlijke keerzijde van schuldbesef kan of moet hebben, staat niet aan ons om uit te maken.' ${ }^{45}$ Noordmans besluit: 'Er is in het Evangelie nog meer dan de kerk zich daaruit heeft toegeëigend.' Daar bedoelt hij mee dat de kerk zich te eenzijdig op de kwestie zonde-genade gericht heeft. Hier kan ook geattendeerd worden op tal van meditaties waaruit blijkt dat Noordmans oog had voor het aardse leven met allerlei vormen van lichamelijke nood. ${ }^{46}$

Over 'het aardse leven' gesproken: in dit verband moeten ook de fragmenten uit de brieven die Noordmans in de jaren 1944 en 1945 (en een brief uit 1950) aan zijn beide kinderen R.A. van Ganswijk-Noordmans en J.A. Noordmans geschreven heeft, genoemd worden ${ }^{47}$ Ook daaruit wordt duidelijk dat bij hem van wereldmijding geen sprake was. De rauwe werkelijkheid van de oorlogstijd is zeker niet aan hem voorbijgegaan.

43 Noordmans, a.w., 510.

44 Noordmans, 'Zondaar en bedelaar', in: $V W$ dl. 8, 15-25.

45 Noordmans, a.w., 25.

46 Zie bijv. Noordmans, 'De misdeelden', in: $V W$ dl. 8, 294-296.

47 Zie 'Fragmenten uit brieven van Noordmans aan zijn beide kinderen R.A. van GanswijkNoordmans en J.A. Noordmans', in: $V W$ dl. 9B, 987-1008. 


\section{Kerk en liturgie}

In het kader van het aardse leven moeten ook kerk en liturgie aan de orde komen. Eric Bouter heeft gesteld dat de kerk in Noordmans' dogmatiek maar moeilijk gestalte aanneemt. ${ }^{48}$ In dat verband spreekt hij over het verwijt van een zeker spiritualisme aan Noordmans' adres. Wie die beschuldiging uit, heeft enig recht van spreken, naar het lijkt. Noordmans noemt de kerk 'de schamelste en armste levensvorm, die wij op aarde kennen'; 'een armoedige verschijning in het mensenleven', 'noodinstelling, toevluchtsoord'; 'een anachronisme'. ${ }^{49}$ Maar er is ook een andere kant. Hij heeft zich ernstig en langdurig ingespannen voor het concrete kerkelijke leven, in het bijzonder in de aanloop naar de nieuwe kerkorde van de Nederlandse Hervormde Kerk van 1951. ${ }^{50}$ Bouter erkent dat. Hij vindt dan ook dat Noordmans 'niet helemaal' docetist is. Ik zou eerder willen stellen dat hij helemaal geen docetist is.

Noordmans heeft zich verzet tegen de vernieuwing van de liturgie zoals die in de liturgische beweging tot ontwikkeling kwam. Hij vreesde dat de verkondiging van het Woord en de bediening van de sacramenten in een cultisch systeem opgesloten zouden worden. Dan zou het evangelie achter mysteriën schuilgaan. Noordmans wilde dat het heil het karakter van een openbare proclamatie zou hebben en zo als boodschap tot de wereld zou komen. Ik geef twee citaten door uit Liturgie, die dat verhelderen. Nadat hij gezegd heeft dat van Straatsburg de victorie begonnen is, omdat men de godsverering daar niet tot een liturgisch stelsel gemaakt heeft, merkt hij met instemming op: 'Men laat Woord en sacrament niet opgaan in cultische mystiek, maar houdt de kerk open naar het leven. ${ }^{51}$ En in aansluiting aan de Liturgia Sacra van Valerandus Pollanus stelt hij: 'Dat God in de eredienst is zal 't meest moeten blijken in het leven; dat Hij er op de zondag was, zal moeten uitkomen doorde-week. ${ }^{52}$ Het is wel duidelijk: de liturgie moet zich niet in hemelse sferen

48 Zie Eric Bouter, Geloven op gezag. Een kritische analyse van de Newmanreceptie bij Noordmans inzake de Kerk en de wending naar het subject, Zoetermeer 2016, 287.

49 Zie Noordmans, 'Het wezen der christelijke vrijheid', in: $V W$ dl. 6, 239; 'Het kerkbegrip als achtergrond van de kerkorde', in: $V W$ dl. 10, 64; 'Zondaar en bedelaar', 29. Vgl. C.P. Boele, Noordmans, de filosofie en christelijk leiderschap, Zoetermeer 2013, 62.

50 Zie Noordmans, $V W$ dl. 5. Vgl. W. Balke, 'De signalen van Noordmans', in: W. Balke, A. van de Beek en J.D.Th. Wassenaar (red.), De kerk op orde? Vijftig jaar hervormd leven met de kerkorde van 1951, Zoetermeer 2001, 67-89.

51 Noordmans, Liturgie, in: VW dl. 6, 60.

52 Noordmans, a.w., 61. 
begeven, maar zich op het aardse leven richten. Met andere woorden: geen contemplatie waarbij geen oog is voor de concrete werkelijkheid.

Blei heeft in zijn lezing op het in 'Aanleiding en inleiding' genoemde congres van de Vereniging voor Theologie onder de aandacht gebracht dat dezelfde kwestie al eerder in het geding was geweest, en wel in de discussie van Noordmans met W.J. Aalders. ${ }^{53}$ In 1935 ziet Noordmans dat er zich in die tijd als het ware een contemplatieve wending voltrekt: 'Overal verlangt men van het verstand, van de geest, tot de zaak, het leven terug te keren. Men zoekt een meer directe benadering van het mysterie des levens. De copernicaanse wending in het denken, waarop Kant zo trots was, wil men weer omkeren. ${ }^{54}$ Noordmans keert zich tegen die tendens. Hij stelt, wat al uit de titel 'Mysterie of boodschap' van zijn artikel blijkt, 'boodschap' tegenover 'mysterie'. Waar Aalders in zijn concentratie op de incarnatie als realiteit uitkomt bij het mysterie, bekruipt Noordmans het gevoel van inkapseling: 'Het mysterieuze, de cultus en de aanbidding, zoals hij [Aalders] die kent, vooronderstellen beslotenheid. 55 Daartegenover kiest Noordmans de partij van de 'dialectische theologie' met haar accent op 'prediking die rauw over de wereld gaat'. Het is volgens Blei niet zo dat Noordmans zich tegen contemplatie als zodanig keert, veeleer is het hem te doen om de roep: 'van de contemplatie terug tot het leven'. ${ }^{56}$

\section{Een open leven}

Van wereldmijding was bij Noordmans geen sprake, hij had wel degelijk oog voor het aardse leven, ook dat van kerk en liturgie. Dat neemt niet weg dat hij zeker een contemplatieve levenshouding had. Hij had iets visionairs. Steeds hield hij het koninkrijk der hemelen voor ogen. Dat visionaire blijkt al uit de titels van enkele artikelenbundels: Geestelijke Perspectieven ${ }^{57}$ en Zoeklichten. ${ }^{58}$ Opvallend is ook het woord 'open' in het oeuvre van Noordmans. Vaak tekent hij het leven uit het evangelie als een verlossing uit de gesloten cirkel van het bestaan. In de meditatie 'Een open leven'59 over Lucas 2:25-35 gebruikte Noordmans enkele treffende beelden om te verduidelijken wat hij met een open leven bedoelde. Over Simeon zegt hij: 'Deze oude van dagen behoeven

53 Noordmans, 'Mysterie of boodschap', in: VW dl. 4, 180-190.

54 Noordmans, a.w., 182.

55 Noordmans, a.w., 187.

56 Noordmans, a.w., 181.

57 Noordmans, Geestelijke perspectieven, Amsterdam 1930¹, $1939^{2}$.

58 Noordmans, Zoeklichten, Amsterdam 1949.

59 Noordmans, 'Een open leven', in: $V W$ dl. 8, 62v. 
wij niet te beklagen, omdat zijn leven voorbij is. Het gebeurt maar al te dikwijls, dat een mens zichzelf of anderen beklaagt, omdat zijn leven kort. Dan ziet hij terug op dat voorbije leven en zou het eigenlijk nog eens willen beginnen. Dan is leven een melancholiek werk, een mistroostige geschiedenis. Dan kijkt iemand naar de jongeren zoals de kinderen, die een stuk koek verorberen en waarbij de ene afgunstig kijkt naar de ander, die het nog niet op heeft.

Zo'n leven, dat is levend begraven worden, want ieder jaar dat voorbij gaat, is een plank aan uw doodkist, waarmee u het licht betimmerd wordt. Voor de gelovige is het juist andersom. Het gaat hem als een bergbeklimmer, die, hoe verder hij gaat, des te hoger stijgt. Dan wordt het uitzicht ruimer en de horizon wordt wijder. Dan vallen de grenzen van het leven weg en alles gaat open. - Maar dan is nu reeds ieder jaar, dat voorbijgaat, gelijk aan het wegnemen van een belemmering voor het uitzicht. Voor de gelovige wordt de doodkist niet getimmerd, maar afgebroken. ... Alleen wie buiten zijn leven en over het kerkhof heen kan zien, heeft een open leven. Dan zullen alle dingen in vervulling gaan. Want de beloften Gods liegen niet. Wij hebben Christus, in doeken, dat is in Gods beloften gewikkeld; en ieder die naar de kribbe gaat en Hem ziet, die ziet Gods zaligheid en kan in vrede heengaan uit dit leven.'

J.D.Th. Wassenaar is als predikant verbonden aan de Protestantse Gemeente te Hellendoorn en als geassocieerd onderzoeker aan de Protestantse Theologische Universiteit. 